\title{
IMPACT OF GROSS DOMESTIC PRODUCT CHANGE ON MUNICIPAL SOLID WASTE GENERATION IN MAPUTO, MOZAMBIQUE
}

\author{
AMAD H. A. GANI ${ }^{1}$, ANTÓNIO G. DIAS ${ }^{2} \&$ ANTÓNIO A. R. MONJANE ${ }^{1}$ \\ ${ }^{1}$ Universidade Pedagógica de Maputo, Faculdade de Ciências Naturais e Matemática, Mozambique \\ ${ }^{2}$ Universidade do Porto, Faculdade de Ciências, Departamento de Geociências, \\ Ambiente e Ordenamento do Território, Portugal
}

\begin{abstract}
The generation of Municipal Solid Waste (MSW) in Maputo grew from 2007 to 2017. Annual generation of the MSW increased from 319,010 tons in 2007 to 433,985 tons in 2017 and waste disposal in the dumpsite increased from 127,385 to 365,000 . These numbers indicate that in 2007 , waste disposal in dumpsite it was $39.93 \%$ from the total generated and in 2017 , it was $84.10 \%$ of the total generated. The objective of this paper is to evaluate the evolution of MSW generation in Maputo municipality as a function of population growth and the variation of Maputo City's Gross Domestic Product (GDP) from 2007 to 2017. GDP varied, population and generation of MSW grew at different rates. At this time, the economy slowed down, and GDP fell from $7.4 \%$ to $6.8 \%$ due to the country's financial crisis. Although the national GDP and, consequently, of Maputo city fell significantly during this period, waste generation continued to grow because of the continuous migration of people from the other provinces to the capital city of Maputo. According to INE [1], the population of Maputo city had the lowest national growth, increasing slightly from 1,111,638 inhabitants in 2007 to $1,120,867$ inhabitants in 2017, representing a population growth of $0.8 \%$. During this period, MSW generation increased by $26.50 \%$. The average capitation rate increased slightly from $0.96 \mathrm{~kg} /$ (inhab.day) in 2007 to $1.06 \mathrm{~kg} /$ (inhab.day).

Keywords: generation, dumpsite, Maputo, Gross Domestic Product (GDP), Municipal Solid Waste $(M S W)$, capitation rate.
\end{abstract}

\section{INTRODUCTION}

Solid waste is the set of materials with solid consistency that the holder intends or needs to discard and may include what is left of the raw materials after use and which cannot be considered as a by-product or product [2]. Levy and Cabeças [2], defined MSW as similar material in consistency and nature generated from service and commercial sectors. The Municipal Solid Waste Management Regulation (MSWMR) of Maputo City defines MSW as being originating from domestic and commercial activities of settlements. The city's growth, emerging neighborhoods without an organized urban structure, coupled with the influx of people from other provinces and insufficient Eco-points, pressures consumer demand, making the MSWM in Maputo a major challenge.

The increase in consumer culture, combined with the growth of the world [3] and urban [4], population, change the standard consumption due to the long period of absence of their homes during the day. These changes led to an inevitable change in the economic and environmental framework [3]. MSW generation in Maputo follows the consumerist trend caused by the country's economic growth. Oliveira et. al. [3], understands that young people with a high academic level and new entrepreneurs are beginning to gain awareness of environmental responsibilities in relation to the MSW management. This awareness is growing, and it is noted that more and more people are sorting out MSW before and after being disposed of in the municipal Hulene dumpsite, with earnings for their family incomes. Aderoju et. al. [5], understands that MSWM is not only the responsibility of the government, 
but also requires self-discipline, change in people's perception and attitude to build a sustainable environment.

The annual world average of MSW generation is, according to Mantovani et al. [6], 1.4 billion tons, resulting in a per capita average of $1.2 \mathrm{~kg} /$ (inhab.day) while Kasaki and Kawai [7], which analyzed capitation rates from 157 countries, noted that the lowest capitation rate in the world is from the Ghana with $0.09 \mathrm{~kg} /$ (inhab.day), the highest is from the Antigua and Barbuda with $5.50 \mathrm{~kg}$ /(inhab.day) and the annual world average of $0.94 \mathrm{~kg} /$ (inhab.day). Mozambique's average capitation rate is $0.14 \mathrm{~kg} /($ inhab.day), being the second lowest rate in the world after Ghana [7]. By contrast, the average capitation rate of EU countries is $1.22 \mathrm{~kg} /$ (inhab.day). This study is intending to evaluate the MSW generation in Maputo municipality as a function of population growth and the variation of Maputo City's Gross Domestic Product (GDP) from 2007 to 2017.

\section{STUDY AREA}

Maputo city is located on the western shore of Maputo Bay in the far south of the country, near South Africa and Swaziland borders. The boundaries of the Maputo municipality lie between the latitudes $25^{\circ} 49^{\prime} 09^{\prime \prime} \mathrm{S}$ and $26^{\circ} 05^{\prime} 23^{\prime \prime} \mathrm{S}$ and the longitudes $33^{\circ} 00^{\prime} 00^{\prime \prime} \mathrm{E}$ (on Inhaca island) and $32^{\circ} 26^{\prime} 15^{\prime \prime} \mathrm{E}$ and at an average elevation of $47 \mathrm{~m}$. The municipality has an area of about 346.77 square kilometers and a population density of $35 \mathrm{inhab} / \mathrm{km}^{2}$. About $60 \%$ of the municipality's works in the informal sector, with the remaining $40 \%$ of the population in the formal sector divided into fisheries, agriculture, manufacturing, tourism and services. Throughout the year, the temperature ranges from $16^{\circ} \mathrm{C}$ to $29^{\circ} \mathrm{C}$ and is rarely below $14^{\circ} \mathrm{C}$ and can often exceed $40^{\circ} \mathrm{C}$ in the rainy season.

Maputo municipality consists of 7 municipal districts, namely: KaMpfumo, KaNlhamankulo, KaMaxaquene, Kamavota, KaMubucuane, KaTembe and KaNyaka. The last two districts were not included in this study because of their geographical location. The KaTembe district is located on the southernmost shore of Maputo Bay while the KaNyaka district is an island, so that its waste does not reach to Municipal Hulene dumpsite.

Data published by INE [8], point to a decrease in Mozambique's per capita GDP from US\$ 458 to US\$ 453 between 2007 and 2017. Maputo city has only 4\% of the country's population but contributes with $18.5 \%$ of national GDP. INE [8] points out the sectors of commerce, transport and communications and manufacturing industry as the most significant, contributing respectively, with $29.6 \%, 29.5 \%$ and $12.4 \%$ of national generation. Mozambique has 53 municipalities and Maputo is the largest municipality in the country.

Trade is characterized by two types of markets: formal, comprising the retail and wholesale network, and informal, comprising fixed and mobile retailers scattered throughout the city streets and through formal and informal markets. In the Infulene green belt, a variety of vegetables are produced. In many suburban neighborhoods, poultry, rabbits and pigs are raised.

In urban neighborhoods, sanitation is served by a conventional domestic and rainwater sewage drainage system built in the colonial era and in older and emerging suburban neighborhoods, consisting essentially of septic tanks, generally unconnected to the public sewage drainage system. In terms of environmental legislation, the municipality has legal and normative MSWM instruments in which each of them complements in the absence of a more appropriate policy, namely:

- Decree 94/2014, of December 31st: Regulation on Urban Waste Management) [9];

- Resolution No. 86/AM/2008, of May 22nd, Posture of Cleaning of Solid Urban Waste in the Municipality of Maputo [10]; and

- $\quad$ Solid Waste Management Master Plan (SWMMP) [11]. 


\subsection{Case study}

Hulene's dumpsite is the case study of this work. It is located about $7 \mathrm{~km}$ from Maputo city center and with the coordinate of the $25^{\circ} 54^{\prime} 03^{\prime \prime} \mathrm{S}$ and $32^{\circ} 35^{\prime} 55^{\prime \prime} \mathrm{E}$ at the center point (Fig. 1). The dumpsite has been operated since 1972 and reached the end of its useful life in 2016 and extended in 2018 for another 10 years due to compaction work. The dumpsite occupies an area of 17 hectares and has a maximum accumulated waste height of about $15 \mathrm{~m}$.

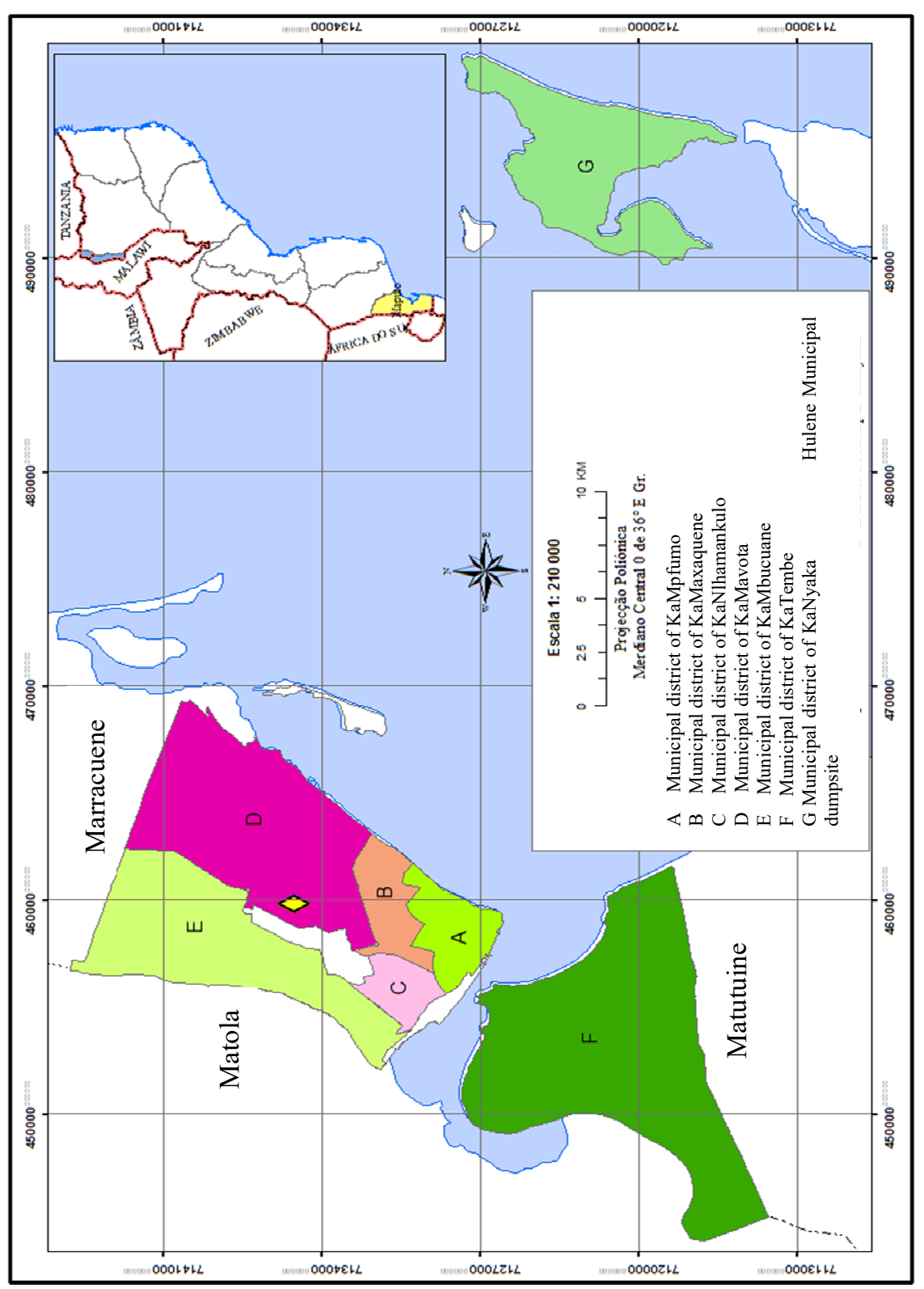

Figure 1: Location of Municipal Hulene dumpsite. 
For the purposes of this study, MSW generation data were made public by the Maputo Municipal Council (MMC). GDP and population data are those officially published by the National Institute of Statistics (INE) of Mozambique in April 2019 and available on the internet and on the Government of Mozambique website.

The raw data of the paper/cardboard and disposable paper fractions were grouped and designated according to the urban solid waste segregation categories (Decree No. 94/2014), in paper/cardboard; the glasses and glass bottles were grouped into glasses; soft and hard plastics were grouped into plastics. The average solid waste generation was calculated using the following equation:

$$
M S W g=(W u \cdot 0.25)+(W s \cdot 0.75)
$$

where

- $\quad M S W g=$ Municipal Solid Waste generation,

- $\mathrm{Wu}=$ Waste generated in the Urban neighborhoods

- $\mathrm{Ws}=$ Waste generated in the Suburban neighborhoods

GDP per capita is the gross domestic product divided by midyear population. Maputo's GDP was calculated, considering the contribution of Maputo city indicated by INE [9], as $18.5 \%$ of national GDP. The capitation rate was calculated, considering the daily generation of MSW, divided by the number of the city's population.

\section{COMPOSITION OF MSW GENERATED IN MAPUTO}

According to Article 14 of the Maputo MSWMR, waste is segregated according to the following categories: paper/cardboard, organic matter, rubble, plastic, glass, metal, textiles, rubber, bulky household waste and special waste. The annual disposal of municipal waste in Hulene dumpsite increased from 127,385 tons in 2007 to 365,000 tons in 2017 (Table 1). During this period, the collection capacity also increased from $39.3 \%$ to $84.10 \%$.

Table 1: MSW generation and disposal in Hulene dumpsite, GDP and capitation rate.

\begin{tabular}{|l|c|c|c|c|c|c|c|}
\hline Year & $\begin{array}{c}* \text { MSW } \\
\text { Generation } \\
\text { (Ton/day) }\end{array}$ & $\begin{array}{c}\text { MSW } \\
\text { Generation } \\
\text { (Ton/year) }\end{array}$ & $\begin{array}{c}* \text { MSW } \\
\text { Disposal } \\
\text { (Ton/day) }\end{array}$ & $\begin{array}{c}* \text { MSW } \\
\text { Disposal } \\
\text { (Ton/year) }\end{array}$ & $\begin{array}{c}\text { Maputo } \\
\text { GDP }\end{array}$ & $\begin{array}{c}* * \text { National } \\
\text { GDP }\end{array}$ & $\begin{array}{c}\text { Capitation rate } \\
\text { (kg/(inhab.dia) })\end{array}$ \\
\hline 2007 & 874 & 319,010 & 349 & 127,385 & 1.37 & 7.4 & 0.97 \\
\hline 2008 & 972 & 354,780 & 437 & 159,505 & 1.28 & 6.9 & 0.99 \\
\hline 2009 & 1,080 & 394,200 & 560 & 204,400 & 1.18 & 6.4 & 1.00 \\
\hline 2010 & 1,093 & 398,945 & 650 & 237,250 & 1.24 & 6.7 & 1.01 \\
\hline 2011 & 1,106 & 403,690 & 700 & 255,500 & 1.31 & 7.1 & 1.02 \\
\hline 2012 & 1,120 & 408,800 & 780 & 284,700 & 1.33 & 7.2 & 1.03 \\
\hline 2013 & 1,133 & 413,545 & 850 & 310,250 & 1.31 & 7.1 & 1.04 \\
\hline 2014 & 1,146 & 418,290 & 900 & 328,500 & 1.37 & 7.4 & 1.04 \\
\hline 2015 & 1,160 & 423,400 & 950 & 346,750 & 1.17 & 6.3 & 1.05 \\
\hline 2016 & 1,174 & 428,510 & 1,000 & 365,000 & 1.11 & 6.0 & 1.06 \\
\hline 2017 & 1,189 & 433,985 & 1,000 & 365,000 & 1.26 & 6.8 & 1.06 \\
\hline
\end{tabular}

Source: Adapted from MMC*, INE**.

The suburban neighborhoods, with about $75 \%$ of the population, are responsible for the average generation of $73 \%$ of organic matter as shown in Fig. 2, against $64 \%$ generated in urban neighborhoods as shown in Fig. 3. Fig. 4 shows the MSW generation in Maputo city 
and it is observed that organic matter is the most commonly produced waste with an average of $71 \%$.

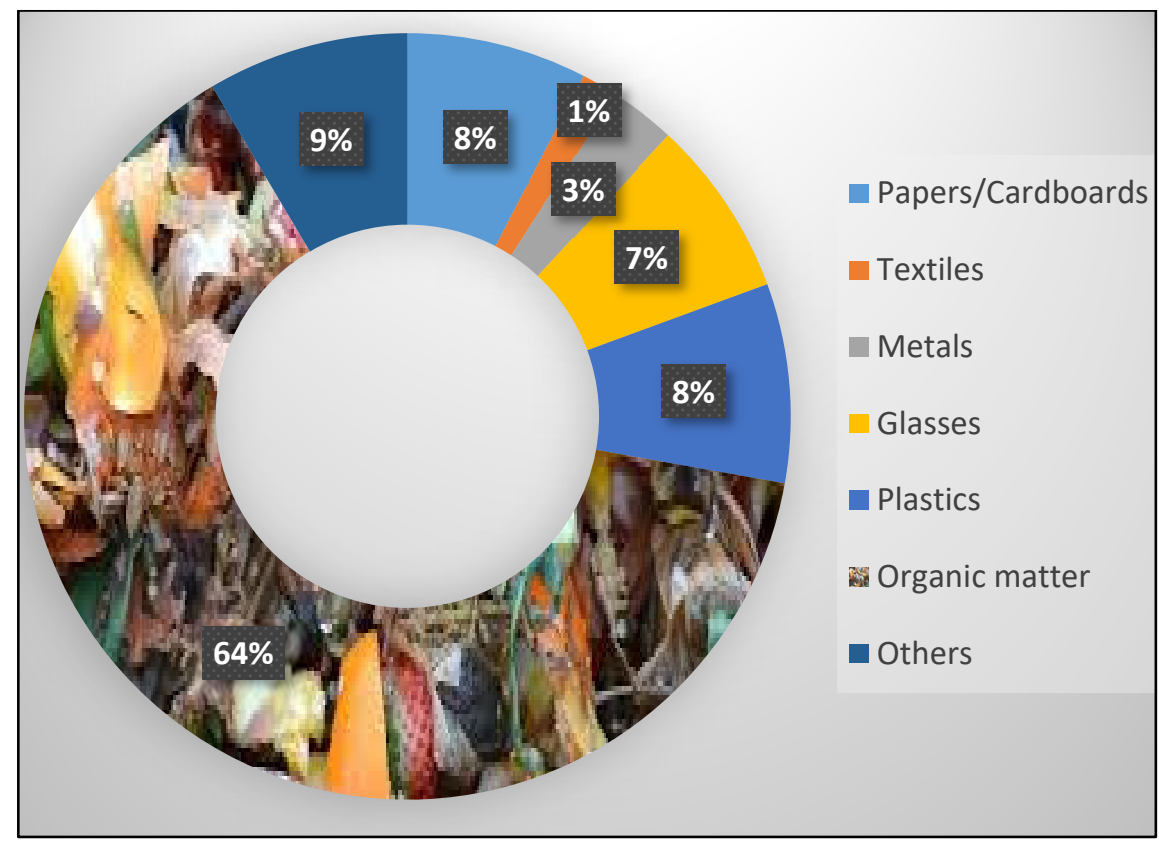

Figure 2: MSW generated in Urban neighborhoods.

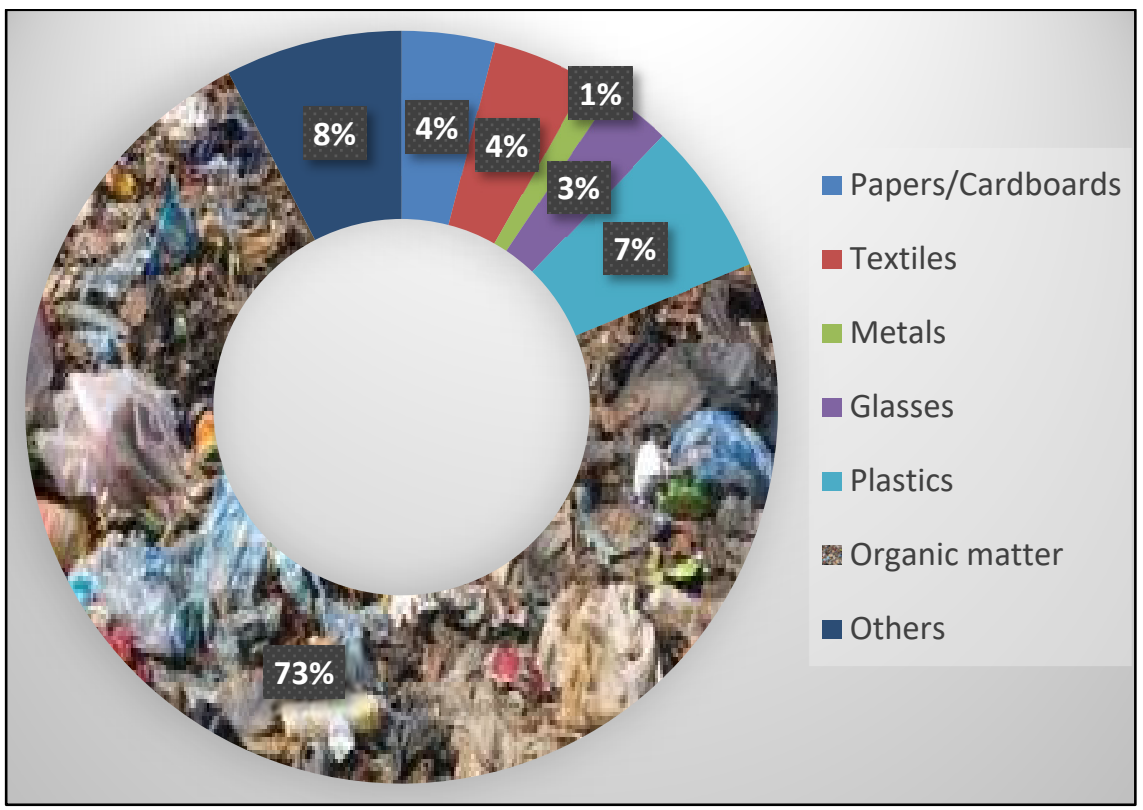

Figure 3: MSW generated in Suburban neighborhoods. 


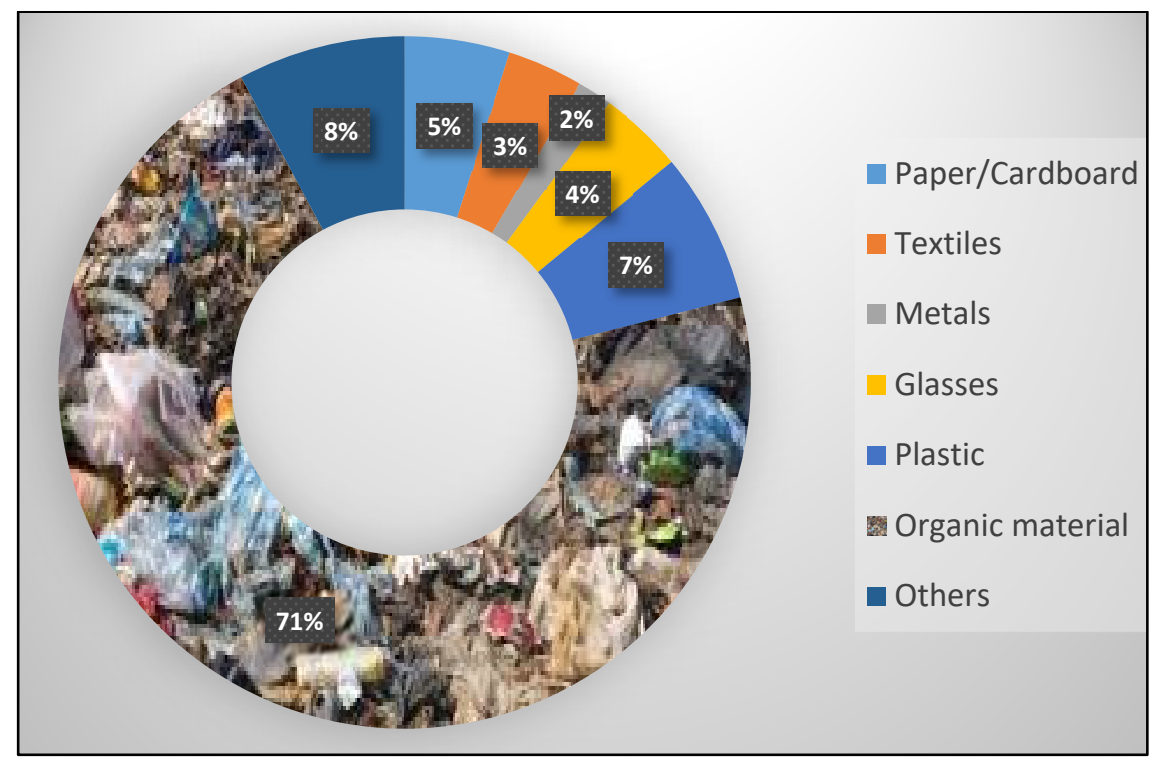

Figure 4: MSW generated in Maputo.

The MSW generated in Maputo city mostly are as follows: paper/cardboard, textiles, glass, metals, plastic, organic matter, and others. Bulky household waste, including construction waste, is used in foundations of new building under construction. The Hulene dumpsite does not receive this kind of waste.

Waste pickers essentially collect waste such as cardboard, plastics, pet and glass bottles, cans and metals selling them to companies that export to South Africa. Metal \& Paper, Lda, a South African company, bought in 2018, 218,270 tons of cardboard and cover boxes at a cost of 3.0 meticais per kilogram, getting a yield of 654.810 million meticais (about US\$9.6 million).

The evolution of MSW generation in Maputo over the years as a function of GDP behavior is shown in Fig. 5.

From 2007 to 2017, the population of Maputo City grew by $0.8 \%$ and MSW generation increased by $26.5 \%$. At the same period, the economy slowed, and GDP fell from $7.4 \%$ to $6.8 \%$ due to the country's financial crisis. This is due the continuous migration of people from the other provinces to the capital city of Maputo. The average capitation rate increased slightly from $0.96 \mathrm{~kg}$ /(inhab.day) in 2007 to $1.06 \mathrm{~kg}$ /(inhab.day) in 2017 (Fig. 6). By comparison, the average capitation rate in green economies according to Elagroudy [12], is $1.2 \mathrm{~kg}$ /(inhab.day). Johannesburg's capitation rate determined by Masebinu et al. [13], for a high-income population averages is $1.91 \mathrm{~kg} /$ (inhab.day); middle-income class yields average $1.01 \mathrm{~kg} /$ (inhab.day) and lower-income class yields average is $0.92 \mathrm{~kg} /$ (inhab.day). The average capitation rate of Maputo city is equivalent to the average capitation rate of the middle-income class population of Johannesburg. The average capitation rate of the Lisbon city is $1.56 \mathrm{~kg} /$ (inhab.day) [14]. Fig. 7, show the MSW generation in Maputo city compared with capitation rate and Fig. 8, shows the average capitation rate of some cities in EU countries and Johannesburg, in South Africa, compared with Maputo city. 


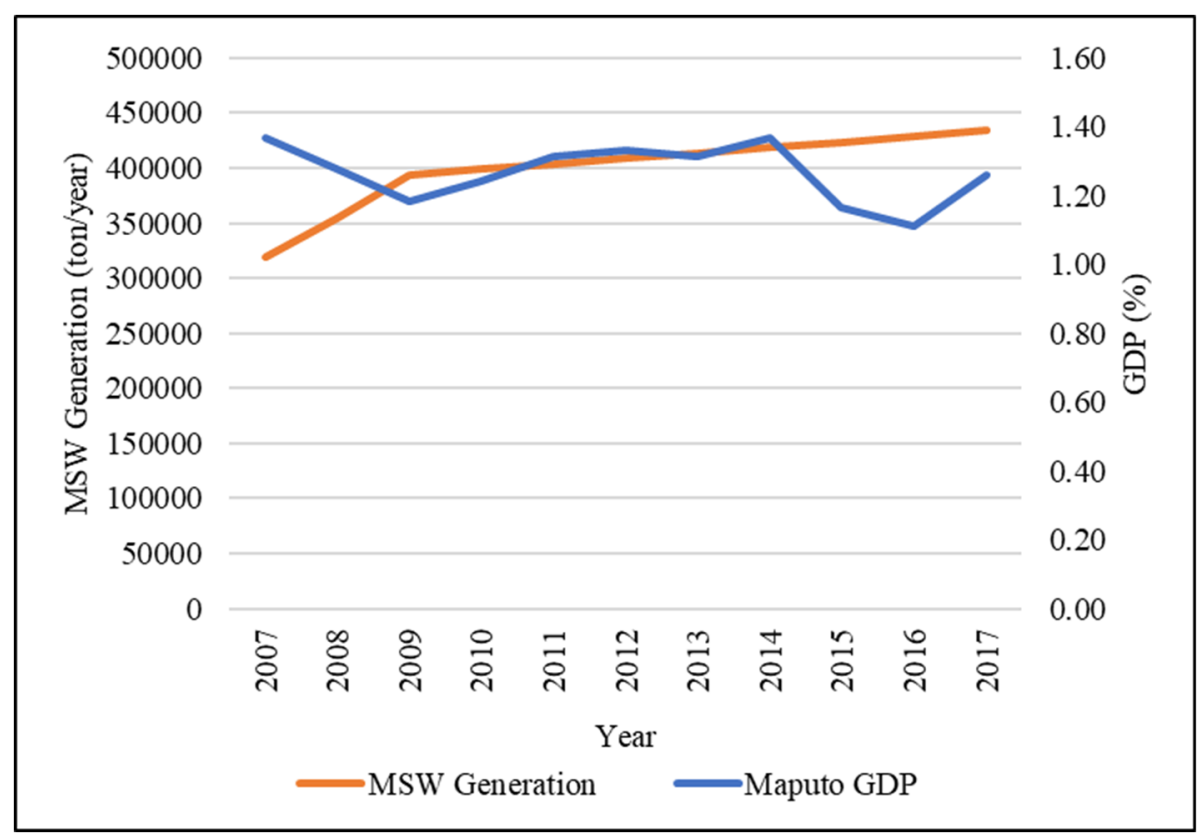

Figure 5: MSW Generation and GDP.

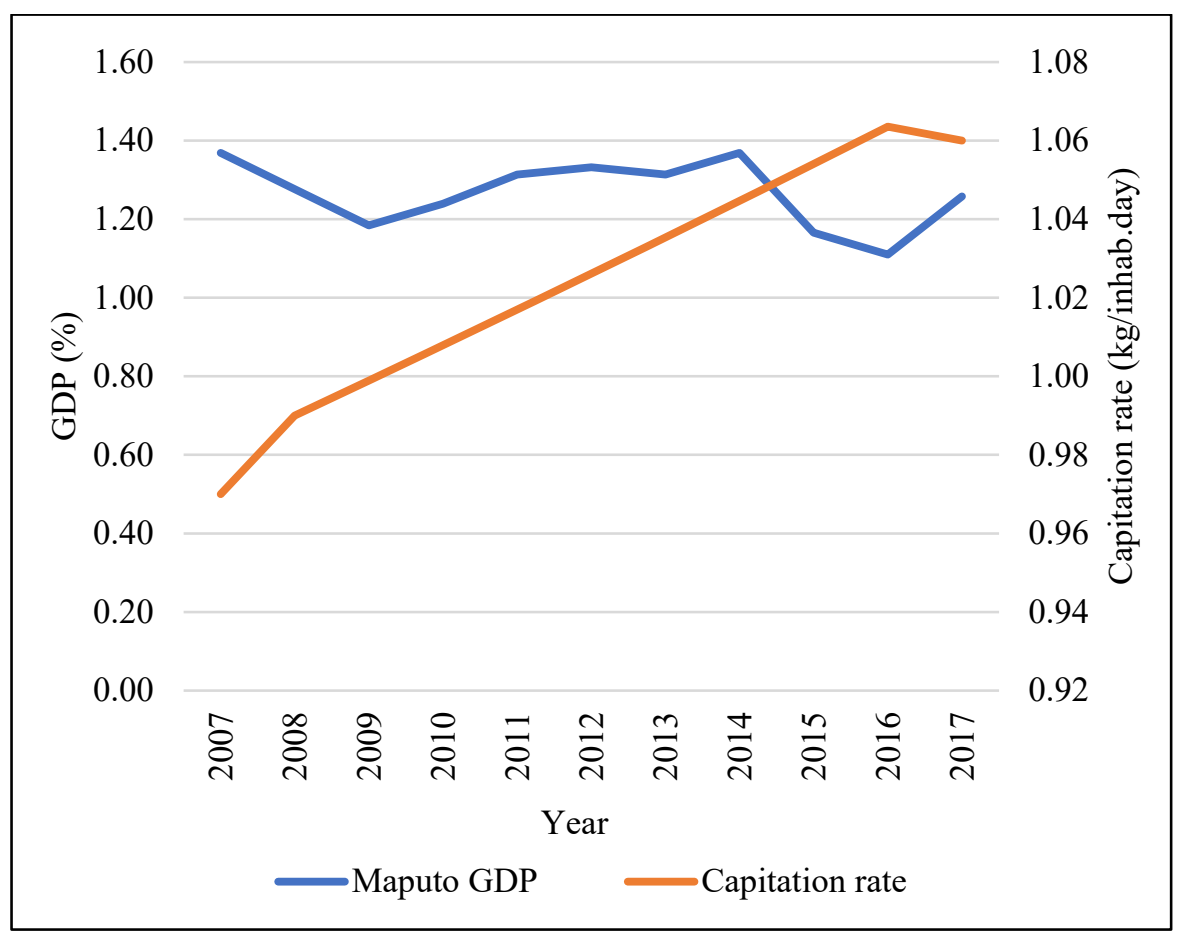

Figure 6: Capitation rate and GDP. 


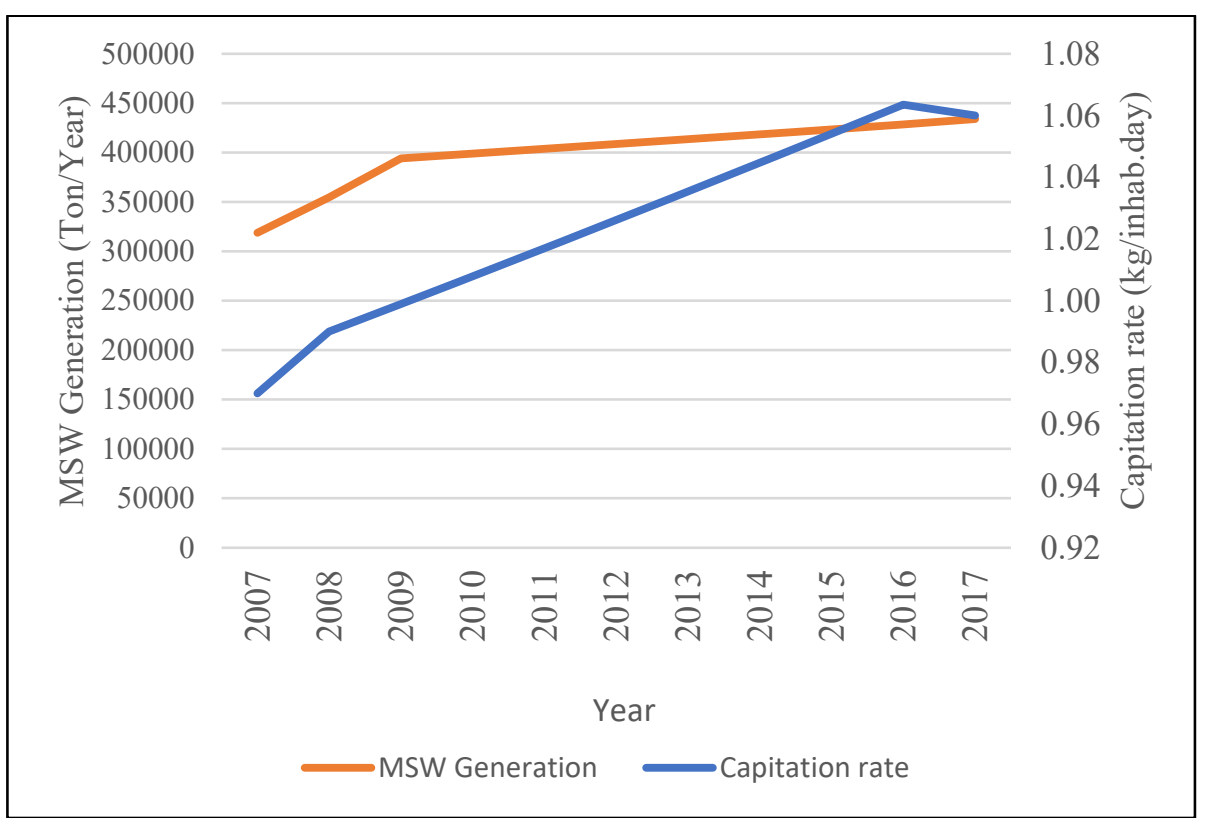

Figure 7: MSW Generation and Capitation rate.

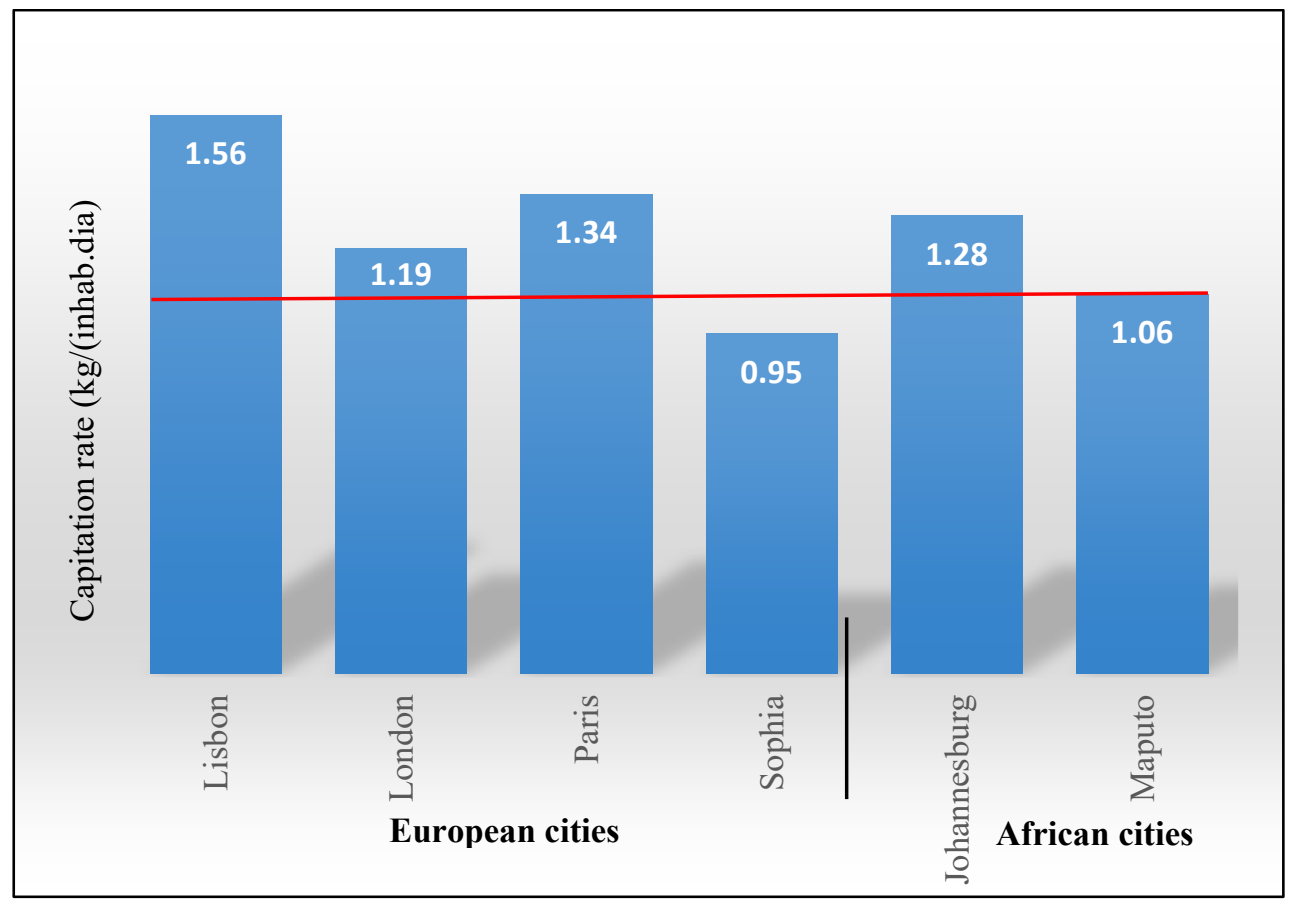

Figure 8: Capitation rates of the EU and African cities. (Source: Adapted from Masebinu et al. 2017 [13] and Brussels DG ENV 2015 [14].) 


\section{CONCLUSION}

The city's population grew by $0.8 \%$ and MSW generation increased by $26.5 \%$. Although national GDP fell from $7.4 \%$ in 2007 to $6.8 \%$ in 2017 with some variation, MSW productions continued to grow. The average capitation rate of Maputo city grew over the same period from $0.97 \mathrm{~kg} /$ (inhab.day) to $1.06 \mathrm{~kg}$ /(inhab.day) and is close to the average capitation rate of the middle-class population of Johannesburg. This rate is above the average capitation rate of the Sofia city and below the Lisbon, London and Paris cities and above of the average Mozambique capitation rate.

Organic matter produced in Maputo is the largest fraction of MSW, with a total of $71 \%$, indicating higher demand for food compared to other products. Suburban neighborhoods with $75 \%$ of the population, produce $73 \%$ of organic matter against $64 \%$ of urban neighborhoods that have $25 \%$ of the city's population. In contrast, the production of paper/cardboard, textile, glass, metal, plastic, and other fractions in urban neighborhoods is $36 \%$, while in suburban neighborhoods is $27 \%$. Over the period studied, the effectiveness of the MSW collection system in Maputo City increased from $39.93 \%$ to $84.10 \%$, representing a growth of $44.17 \%$ and a difference of 237,615 tons of waste disposed.

[1] INE, Apresentação dos Resultados do IV Recenseamento Geral da População, Censo de 2017. Instituto Nacional de Estatística de Moçambique, Maputo 2019. www.ine.gov.mz.

[2] Levy, J.P. \& Cabeças, A.J., Resíduos Sólidos Urbanos - Princípios e Processos, $1^{\mathrm{a}}$ Edição, Editado por AEPSA: Lisboa, 2006. ISBN: 989-95059-0-0.

[3] Oliveira, F.F.S., Mendes, B. \& Lapa, N., Resíduos. Gestão, Tratamento e sua Problemática em Portugal, LIDEL, Lisboa, p. 71, 2009. ISBN: 978-972-757-504-6.

[4] Yoshida, M. \& Agency, C., Situation of Municipal Solid Waste Management in African Cities - An Interpretation of the Information provided by the First ACCP Meeting, 1(June), 2000-2015, 2018.

[5] Aderoju, O.M., Dias, A.G. \& Guimarães, R., Wastes: Solutions, Treatments and Oportunities, eds, Vilarinho, Castelo \& Russo, London, ISBN 978-1-138-02882-1, 2015.

[6] Mantovani, B., Cavion, G. \& Finkler, R., Geração de Resíduos Sólidos Urbanos e o Produto Interno Bruto (PIB): Análise da Realidade de Caxias do Sul-Rio Grande do Sul, 2017.

[7] Kasaki, T. \& Kawai, K., Revisiting Estimates of Municipal Solid Waste Generation Per Capita and Their Reliability, 3R Policy Maker, Japan, 2015.

[8] INE, PIB Provincial de 2007 a 2017, Maputo, 2019. www.ine.gov.mz/estatisticas/ estatisticas-economicas/contas-nacionais/anuais-1/pib-provincial-2007-2013-2017quadros/at_download/file.

[9] Decree No. 94/2014, Regulation on municipal waste management, Maputo, 31 December 2014.

[10] Resolução Resolution No. 86/AM/2008, Posture of cleaning of solid municipal waste in the Municipality of Maputo, Maputo, 22 May 2006.

[11] Maputo, C.M.C., Solid Waste Management Master Plan (SWMMP), Maputo, 2008. www.giz.de/en/downloads/giz2012-en-economic-instruments-mozambique.pdf.

[12] Elagroudy, S., Warith, M.A. \& Zayat, M., Municipal Solid Waste Management And Green Economy, Global Young Academy Jägerstr: Berlin, Germany, 2016. ISBN: 978-3-939818-65-6. www.globalyoungacademy.net. 
24 Waste Management and the Environment X

[13] Masebinu, S., Akinlabi, E.T., Muzenda, E., Aboyade, A.O., Mbohwa, C., Manyuchi, M. \& Naidoo, P., a review on factors affecting municipal solid waste generation. Presented at: 2nd International Engineering Conference, Federal University of Technology, Minna, Nigeria, 17-19 Oct. 2017.

[14] Brussels, DG ENV, Assessment of separate collection schemes in the 28 capitals of the EU. Final report, Copenhagen Resource Institute, BIPRO: Brussels, 2015. Reference: 070201/ENV/2014/691401/SFRA/A2. 